\title{
UPAYA PENINGKATAN KEAKTIFAN DAN HASIL BELAJAR MATEMATIKAMELALUI PENDEKATAN CONTEXTUAL TEACHING AND LEARNING (CTL) BERBANTUAN ALAT PERAGA PADA SISWA KELAS 5 SDN LODOYONG 03 - AMBARAWA TAHUN PELAJARAN 2013/2014
}

\author{
Nova Dinda Taurina \& Wasitohadi \\ Pendidikan Guru Sekolah Dasar - FKIP - UKSW Salatiga
}

\begin{abstract}
ABSTRAK
Penelitian ini didasarkan pada kenyataan bahwa guru kurang optimal dalam pembelajaran matematika. Metode pembelajaran yang sering digunakan adalah ceramah, dan guru tidak menggunakan alat peraga dalam pembelajaran. Hal tersebut menyebabkan rendahnya keaktifan siswa dan berdampak pada rendahnya hasil belajar mereka. Sebanyak $62 \%$ atau 13 siswa dari 21 siswa tidak dapat mencapai nilai $\geq \mathrm{KKM}$ sebesar 70 . Berdasar dari permasalahan tersebut, maka penelitian ini bertujuan untuk meningkatkan keaktifan dan hasil belajar matematika pada siswa kelas 5 SDN Lodoyong 03 Kecamatan Ambarawa Tahun Pelajaran 2013/2014 melalui pendekatan CTL berbantuan alat peraga. Jenis penelitian ini adalah penelitian tindakan kelas atau PTK. Model PTK yang digunakan adalah model Kemmis dan Taggart yang terdiri dari empat tahapan yaitu tahap perencanaan, pelaksanaan, observasi, dan refleksi. Adapun yang menjadi subyek penelitian ini adalah siswa kelas 5 SDN Lodoyong 03 berjumlah 21 siswa, yang terdiri dari 14 siswa laki-laki dan 7 siswa perempuan. Teknik pengumpulan data menggunakan teknik tes, observasi, wawancara dan dokumentasi. Instrumen penelitiannya berupa lembar evaluasi berbentuk isian dan uraian, lembar observasi aktivitas guru dan siswa, serta lembar wawancara guru dan siswa. Indikator keberhasilan penelitian ini sebesar $80 \%$ atau sekitar 17 siswa harus mencapai nilai $\geq$ KKM sebesar 70 dan harus aktif dalam pembelajaran. Adapun teknik analisis data yang digunakan adalah analisis ketuntasan dan analisis komparatif. Hasil penelitian menunjukkan adanya peningkatan hasil belajar siswa. Pada pra siklus hanya 8 siswa (38\%) yang tuntas dan 13 siswa lainnya (62\%) belum tuntas. Pada siklus I jumlah siswa yang tuntas meningkat menjadi 13 siswa (62\%), sedangkan 8 siswa (38\%) belum tuntas. Kemudian pada siklus II meningkat lagi menjadi 17 siswa (81\%) yang tuntas, dan hanya 4 siswa (19\%) yang belum tuntas. Hal tersebut berarti bahwa penelitian ini berhasil, karena telah mencapai indikator keberhasilan penelitian yaitu sebesar $80 \%$. Sedangakan rata-rata tingkat keaktifan siswa pada siklus I hanya 12,3 atau $72 \%$, kemudian pada siklus II meningkat menjadi 15,3 atau 90\%. Sehingga dapat disimpulkan bahwa pendekatan CTL berbantuan alat peraga dapat meningkatkan keaktifan dan hasil belajar matematika pada siswa kelas 5 SDN Lodoyong 03 Kecamatan Ambarawa Tahun Pelajaran 2013/1014.
\end{abstract}

Kata kunci: Pendekatan CTL, Alat peraga, Keaktifan, Hasil belajar matematika. 
Upaya Peningkatan Keaktifan dan Hasil Belajar Matematika melalui Pendekatan Contextual Teaching And Learning (CTL) Berbantuan Alat Peraga (Nova Dinda Taurina \& Wasitohadi)

\section{PENDAHULUAN}

Matematika adalah salah satu mata pelajaran yang penting untuk diajarkan kepada siswa. Menurut BSNP (2006:153), matematika merupakan ilmu universal yang mendasari perkembangan teknologi modern, mempunyai peran penting dalam berbagai disiplin dan memajukan daya pikir manusia. Dari sumber tersebut dijelaskan pula bahwa matematika bertujuan untuk membekali peserta didik dengan kemampuan berpikir logis, analitis, sistematis, kritis, dan kreatif, serta kemampuan bekerjasama.

Begitu pentingnya matematika, maka tak heran apabila matematika diajarkan kepada siswa di semua jenjang pendidikan mulai dari Taman Kanak-kanak sampai perguruan tinggi. Namun seringkali siswa bahkan mahasiswa masih mengalami kesulitan dalam belajar matematika. Hal tersebut juga dialami oleh siswa-siswi di Sekolah Dasar (SD) yang peneliti teliti. Berdasarkan kegiatan wawancara yang peneliti lakukan terhadap guru kelas 5 SDN Lodoyong 03 Kecamatan Ambarawa, diperoleh keterangan bahwa sebagian besar siswa kelas 5 mengalami kesulitan belajar pada mata pelajaran matematika di semester II khususnya pada materi pecahan. Data ini didukung dengan hasil belajar mereka yang bersumber dari Ulangan Tengah Semester II Tahun Pelajaran 2013/2014 pada mata pelajaran matematika, dimana dari 21 siswa yang ada terdapat 13 siswa yang tidak tuntas karena memperoleh nilai kurang dari 70 sebagai nilai Kriteria Ketuntasan Minimal (KKM). Sedangkan yang sudah tuntas hanya 8 siswa.

Berdasarkan hasil observasi proses pembelajaran matematika di kelas 5 tersebut, pembelajaran yang dilakukan guru kelas 5 bersifat konvensional karena metode pembelajaran yang digunakan hanya ceramah. Selain itu guru tidak menggunakan media pembelajaran atau alat peraga apapun dalam mengajarkan materi matematika kepada siswa. Selama pembelajaran berlangsung siswa terlihat pasif. Selain itu pembelajaran menjadi monoton karena model interaksinya hanya satu arah yaitu guru ke siswa. Sehingga tingkat keaktifan siswa dalam pembelajaran sangat rendah. Menurut peneliti permasalahan tersebut harus segera diatasi, karena apabila sekarang siswa tidak menguasai materi yang sedang diajarkan, maka siswa akan kesulitan lagi ketika mempelajari materi lanjutan. Berdasarkan masalah tersebut peneliti terdorong untuk memecahkannya melalui penelitian tindakan kelas (PTK), karena PTK bertujuan untuk memecahkan permasalahan nyata yang terjadi di dalam kelas. Supaya PTK benar-benar dapat mengatasi masalah kesulitan belajar siswa secara efektif, maka guru harus melakukan inovasi atau pembaharuan dalam pembelajaran terkait dengan pendekatan, model, metode, atau media pembelajaran. Peneliti mencoba untuk menawarkan pendekatan Contextual Teaching and 
Learning yang selanjutnya disebut dengan CTL dengan bantuan alat peraga sebagai pembaharuan pembelajaran tersebut.

Pendekatan CTL adalah konsep belajar yang membantu guru mengaitkan antara materi yang diajarkan dengan situasi dunia nyata dan mendorong siswa membuat hubungan antara pengetahuan yang dimilikinya dengan perencanaan dalam kehidupan mereka sehari-hari (Depdiknas dalam Kesuma, dkk, 2010:58). Langkahlangkah dalam pendekatan CTL meliputi berbagai aktivitas-aktivitas yang menunjang keaktifan belajar siswa. Sedangkan penggunaan alat peraga dimaksudkan untuk membantu memperjelas materi matematika yang akan diajarkan. Berdasarkan keterangan-keterangan di atas, maka penelitian ini ingin menjawab "Apakah pendekatan CTL berbantuan alat peraga dapat meningkatkan keaktifan dan hasil belajar siswa kelas 5 SDN Lodoyong 03 Kecamatan Ambarawa pada materi matematika?". Adapun tujuan dalam penelitian ini yaitu untuk meningkatkan keaktifan dan hasil belajar matematika pada siswa kelas 5 SDN Lodoyong 03 Kecamatan Ambarawa Semester II Tahun Pelajaran 2013/2014 melalui pendekatan CTL berbantuan alat peraga.

\section{KAJIAN PUSTAKA}

Matematika merupakan mata pelajaran yang penting untuk diajarkan kepada siswa. Menurut Sujono (1988:5), matematika merupakan ilmu pengetahuan tentang penalaran yang logik dan masalah yang berhubungan dengan bilangan. Selain itu mata pelajaran matematika bertujuan agar peserta didik memiliki kemampuan: (a) memahami konsep matematika, menjelaskan keterkaitan antar konsep dan mengaplikasikan konsep atau algoritma, secara luwes, akurat, efisien, dan tepat, dalam pemecaham masalah, (b) menggunakan penalaran pada pola dan sifat, melakukan manipulasi matematika dalam membuat generalisasi, menyusun bukti, atau menjelaskan gagasan dan pernyataan matematika, (c) memecahkan masalah yang meliputi kemampuan memahami masalah, merancang model matematika, menyelesaikan model dan menafsirkan solusi yang diperoleh, (d) mengomunikasikan gagasan dengan simbol, tabel, diagram, atau media lain untuk memeperjelas keadaan atau masalah, (e) memiliki sikap menghargai kegunaan matematika dalam kehidupan, yaitu memiliki rasa ingin tahu, perhatian, dan minat dalam mempelajari matematika, serta sikap ulet dan percaya diri dalam pemecahan masalah (BSNP, 2006:148).

Begitu pentingnya mata pelajaran matematika, maka tak heran apabila matematika diajarkan kepada siswa mulai dari sekolah dasar hingga perguruan tinggi. Namun faktanya matematika sulit untuk dipelajari baik siswa maupun mahasiswa. Oleh karena itu dalam setiap pembelajaran matematika diharapkan dapat menggunakan pendekatan atau model pembelajaran yang inovatif, agar materi matematika dapat 
diterima siswa dengan lebih baik. Ada banyak pendekatan pembelajaran yang inovatif, salah satunya yaitu pendekatan CTL.

\section{Pendekatan CTL}

Secara etimologi, istilah contextual berasal dari kata context yang berarti hubungan, konteks, suasana, dan keadaan (KUBI, 2002:519). Menurut Kesuma, dkk (2010:5), konteks artinya kondisi lingkungan, yaitu keadaan atau kejadian yang membentuk lingkungan dari sebual hal. Dengan demikian pendekatan CTL dapat diartikan sebagai konsep belajar yang membantu guru mengaitkan materi yang diajarkan dengan situasi dunia nyata dan mendorong siswa membuat hubungan antara pengetahuan yang dimilikinya dengan perencanaan dalam kehidupan mereka sehari-hari (Depdiknas dalam Kesuma, dkk, 2010:58). Sedangkan menurut Johnson (2002:67), pendekatan CTL adalah sebuah proses pendidikan yang bertujuan menolong para siswa melihat makna di dalam materi akademik yang mereka pelajari dengan cara menghubungkan subjek-subjek akademik dengan konteks dalam kehidupan keseharian mereka, yaitu dengan konteks keadaan pribadi, sosial, dan budaya mereka.

Pendekatan CTL terbentuk oleh delapan komponen yang melibatkan proses yang berbeda-beda, yang ketika digunakan secara bersama-sama, memampukan para siswa membuat hubungan yang menghasilkan makna (Kesuma, dkk, 2010:6). Delapan komponen tersebut antara lain: (1) membuat hubungan-hubungan yang bermakna, (2) melakukan pekerjaan berarti, (3) melaksanakan proses belajar yang diatur sendiri, (4) bekerja sama, (5) berpikir kritis dan kreatif, (6) membantu individu untuk tumbuh dan berkembang, (7) mencapai standar tinggi, (8) menggunakan penilaian otentik.

Pendekatan CTL memiliki kelebihan dan kelemahan. Ada beberapa kelebihan pendekatan CTL menurut Anisa (2009) dapat diuraikan sebagai berikut.

a. Pembelajaran lebih bermakna, artinya siswa melakukan sendiri kegiatan yang berhubungan dengan materi yang ada sehingga siswa dapat memahaminya sendiri.

b. Pembelajaran lebih produktif dan mampu menumbuhkan penguatan konsep kepada siswa karena pendekatan CTL menuntut siswa menemukan sendiri bukan menghafalkan.

c. Menumbuhkan keberanian siswa untuk mengemukakan pendapat tentang materi yang dipelajari.

d. Menumbuhkan rasa ingin tahu tentang materi yang dipelajari dengan bertanya kepada guru.

e. Menumbuhkan kemampuan dalam bekerjasama dengan teman yang lain untuk memecahkan masalah yang ada.

f. Siswa dapat membuat kesimpulan sendiri dari kegiatan pembelajaran. 
g.

h. Sedangkan menurut Dzaki (2009), beberapa kelemahan pendekatan CTL yaitu:

i. Bagi siswa yang tidak dapat mengikuti pembelajaran, maka tidak akan mendapatkan pengetahuan dan pengalaman yang sama dengan teman lainnya karena siswa tidak mengalami sendiri.

j. Perasaan khawatir pada anggota kelompok akan hilangnya karakteristik siswa, karena harus menyesuaikan diri dengan kelompoknya.

k. Banyak siswa yang tidak senang apabila diminta bekerjasama dengan yang lainnya, karena siswa yang tekun merasa harus bekerja melebihi siswa yang lain dalam kelompoknya.

Penerapan pendekatan CTL dalam pembelajaran harus sesuai dengan langkahlangkahnya. Menurut Nurhadi (2014:106), secara garis besar langkah-langkah dalam pendekatan CTL dapat diuraikan sebagai berikut.

1. Mengembangkan pemikiran bahwa anak akan belajar lebih bermakna dengan cara bekerja sendiri, menemukan sendiri, dan mengkonstruksi sendiri pengetahuan dan keterampilan barunya.

2. Melaksanakan sejauh mungkin kegiatan inkuiri untuk semua topik.

3. Mengembangkan sifat ingin tahu siswa dengan bertanya.

4. Menciptakan 'masyarakat belajar' (belajar dalam kelompok-kelompok).

5. Menghadirkan 'model' sebagai contoh pembelajaran.

6. Melakukan refleksi di akhir pertemuan.

7. Melakukan penilaian yang sebenarnya dengan berbagai cara.

Ketujuh langkah-langkah pendekatan CTL di atas masih terlalu umum, sedangkan dalam penerapannya memerlukan langkah-langkah yang lebih operasional dalam bentuk sintaks pembelajaran. Berikut ini disajikan sintaks pembelajaran pendekatan CTL untuk penerapan pembelajaran matematika pada siswa kelas 5 SDN Lodoyong 03 Kecamatan Ambarawa.

1. Kegiatan Awal

a. Guru menyiapkan siswa untuk mengikuti proses pembelajaran.

b. Guru bersama siswa melakukan tanya jawab tentang pengalaman nyata siswa yang berkaitan dengan materi. (Tahap ke-1, Konstruksi)

c. Menyampaikan tujuan pembelajaran dan pokok-pokok materi yang akan dipelajari.

2. Kegiatan Inti

a. Guru mengajukan suatu permasalahan kontekstual terkait dengan materi pelajaran. (Tahap ke-2, Inkuiri)

b. Siswa diminta untuk mencari penyelesaian dari permasalahan tersebut. (Tahap ke-2, Inkuiri)

c. Guru bersama dengan siswa menyelesaikan permasalahan dengan bantuan alat peraga. (Tahap ke-2, Inkuiri) 
Upaya Peningkatan Keaktifan dan Hasil Belajar Matematika melalui Pendekatan Contextual Teaching And Learning (CTL) Berbantuan Alat Peraga (Nova Dinda Taurina \& Wasitohadi)

d. Guru memberikan kesempatan kepada siswa untuk bertanya.

(Tahap ke-3, Bertanya)

e. Guru membagi siswa secara berkelompok, siswa disediakan alat peraga. (Tahap ke-4, Masyarakat Belajar)

f. Guru mengajukan beberapa soal, siswa bekerja dalam kelompok untuk mengerjakan soal dengan bantuan alat peraga. (Tahap ke-4, Masyarakat Belajar)

g. Guru berkeliling untuk mengamati dan memotivasi setiap kelompok.

h. Siswa mempresentasikan hasil kerjanya di depan kelas, siswa lain diminta untuk menanggapi hasil kerja teman.

i. Guru memberikan umpan balik kepada siswa dan memberikan contoh cara pengerjaan soal yang benar. (Tahap ke-5, Pemodelan)

3. Kegiatan Akhir

a. Guru mengadakan refleksi dengan meminta siswa bersama-sama membuat rangkuman atau kesimpulan tentang materi tersebut. (Tahap ke-6, Refleksi)

b. Guru memberikan soal evaluasi untuk dikerjakan siswa. (Tahap ke-7, Penilaian Sebenarnya)

c. Guru menutup pembelajaran.

\section{Alat Peraga}

Alat peraga atau teaching aids adalah alat-alat yang digunakan guru ketika mengajar untuk membantu memperjelas materi pelajaran yang disampaikannya kepada siswa dan mencegah terjadinya verbalisme pada diri siswa (Usman, 1995:31). Ada bermacam-macam alat peraga, ada yang bersifat konkrit dan semi konkrit. Alat peraga yang bersifat konkrit berupa benda-benda nyata tiga dimensi. Sedangkan alat peraga yang bersifat semi konkrit berupa gambar-gambar.

Pada dasarnya siswa SD sedang berada pada tahap operasional konkrit. Tahap tersebut mengartikan bahwa mereka mampu belajar secara konkrit, mereka belum mampu belajar secara abstrak. Pembelajaran dengan menggunakan alat peraga baik benda konkrit maupun benda semi konkrit, akan membuat pemahaman siswa terhadap materi pelajaran lebih jelas. Selain itu penggunaan alat peraga juga dapat menarik perhatian siswa dalam belajar. Kejelasan pemahaman materi dan ketertarikan dalam belajar ini akan membuat pembelajaran menjadi efektif. Dari penjelasan tersebut beberapa manfaat penggunaan alat peraga dalam pembelajaran antara lain: (1) mengurangi verbalisme, (2) memperbesar perhatian siswa, (3) memberikan pengalaman nyata kepada siswa, (4) membuat materi pelajaran lebih menetap atau tidak mudah dilupakan. 


\section{Hasil Belajar}

Menurut Sudjana (2008:2), hasil belajar adalah kemampuan yang dimiliki siswa setelah menerima pengalaman belajarnya. Bloom dalam Agus (2010:6) mengemukakan bahwa hasil belajar mencakup kemampuan kognitif, afektif, dan psikomotorik. Dari beberapa pernyataan tersebut dapat disimpulkan bahwa hasil belajar merupakan kemampuan yang muncul dalam diri siswa, berupa kemampuan kognitif, afektif, ataupun psikomotorik setelah ia mengalami kegiatan belajar.

Hasil belajar yang dapat dicapai setiap siswa berbeda-beda. Perbedaan tingkat pencapaian hasil belajar tersebut dipengaruhi oleh dua faktor yaitu:

a. Faktor Internal, merupakan faktor-faktor yang berasal dari dalam diri siswa yang meliputi faktor fisiologis dan psikologis. Faktor fisiologis berkaitan dengan kondisi fisik seseorang, sedangkan faktor psikologis berkaitan dengan intelegensi, sikap, bakat, minat, dan motivasi seseorang.

b. Faktor Eksternal, merupakan faktor-faktor yang berasal dari luar diri siswa yang meliputi lingkungan belajar atau keadaan sekolah, guru, sarana-prasarana, cara mengajar guru, mupun metode, model dan media pembelajaran yang digunakan (Syah, 2006:144).

\section{Keaktifan}

Kata keaktifan berasal dari kata aktif yang berarti sibuk, giat (Kamus Besar Bahasa Indonesia, 2003:17). Kata aktif mendapat awalan ke- dan -an, sehingga menjadi keaktifan yang mempunyai arti kegiatan atau kesibukan. Menurut Sardiman (2001:98), keaktifan adalah kegiatan yang bersifat fisik maupun mental, yaitu berbuat dan berfikir sebagai suatu rangkaian yang tidak dapat dipisahkan.

Ada dua macam keaktifan dalam pembelajaran yaitu keaktifan jasmani dan keaktifan rohani. Sriyono, dkk (1992:75) mengemukaan bahwa keaktifan jasmani dan rohani yang dilakukan siswa dalam pembelajaran meliputi: (a) keaktifan indera,

(b) keaktifan akal, (c) keaktifan ingatan, dan (d) keaktifan emosi. Sudjana (2003:48), menyebutkan beberapa kegiatan yang termasuk dalam keaktifan dalam belajar, diantaranya yaitu:

1. turut serta dalam melaksanakan tugas belajarnya,

2. terlibat dalam pemecahan masalah,

3. bertanya kepada peserta didik lain atau kepada guru apabila tidak memahami persoalan yang dihadapinya,

4. berusaha mencari berbagai informasi yang diperlukan untuk pemecahan masalah,

5. melaksanakan diskusi kelompok sesuai petunjuk guru,

6. menilai kemampuan dirinya dan hasil-hasil yang diperolehnya, 
7. melatih diri dalam memecahkan soal atau masalah sejenis,

8. kesempatan menggunakan atau menerapkan apa yang diperolehnya dalam menyelesaikan tugas atau persoalan yang dihadapinya.

\section{Kajian Hasil Penelitian yang Relevan}

Ada beberapa penelitian yang relevan dengan penelitian ini, antara lain penelitian oleh Muhamad Ngainun Najib (2013) yang menerapkan pendekatan CTL dan penggunaan alat peraga untuk meningkatkan hasil belajar IPA. Hasil dari penelitian tersebut yaitu terjadi peningkatan hasil belajar siswa setelah menggunakan pendekatan CTL dan penggunaan alat peraga. Demikian juga dengan penelitian Husni Sabil (2011), yang menerapkan pendekatan CTL dengan model pembelajaran berdasarkan masalah. Penelitian tersebut berhasil karena dapat meningkatkan kualitas dan hasil belajar mahasiswa.

\section{Hipotesis Tindakan}

Berdasarkan uraian teori di atas, hipotesis dalam penelitian ini adalah pendekatan CTL berbantuan alat peraga diduga dapat meningkatkan keaktifan dan hasil belajar matematika pada siswa kelas 5 SDN Lodoyong 03 Kecamatan Ambarawa Semester II Tahun Pelajaran 2013/2014.

\section{METODE PENELITIAN}

Jenis penelitian ini adalah penelitian tindakan kelas (PTK) kolaboratif, yang dilakukan dengan berkolaborasi dengan guru kelas. Model PTK yang digunakan dalam penelitian ini mengacu pada model Kemmis dan Taggart yang terdiri dari empat tahapan yaitu tahap perencanaan, pelaksanaan, observasi, dan refleksi. Penelitian ini dilakukan dalam dua siklus yaitu siklus I dan siklus II, dimana setiap siklusnya dilaksanakan dalam tiga kali pertemuan. Adapun subyek dalam penelitian ini adalah siswa kelas 5 SDN Lodoyong 03 yang berjumlah 21 siswa. Dari 21 siswa tersebut terdiri dari 14 siswa laki-laki dan 7 siswa perempuan. Dalam penelitian ini terdapat dua jenis variabel yaitu variabel bebas dan terikat. Variabel bebas dalam penelitian ini adalah pendekatan Contextual Teaching and Learning (CTL) dan alat peraga. Sedangkan variabel terikatnya adalah hasil belajar dan keaktifan.

Definisi konsep dalam PTK ini: Pendekatan CTL adalah suatu kerangka umum dalam menyelenggarakan pembelajaran bermakna, yang dilakukan guru dengan mengaitkan materi pelajaran matematika tentang pecahan dengan pengalaman atau kehidupan sehari-hari siswa kelas 5 SDN Lodoyong 03 Kecamatan Ambarawa. Alat peraga adalah alat bantu baik berupa benda nyata maupun gambar yang berguna untuk memperagakan atau menjelaskan materi pelajaran matematika tentang pecahan. Hasil belajar adalah skor yang diperoleh siswa kelas 5 SDN Lodoyong 03 Kecamatan Ambarawa setelah melakukan proses pembelajaran di kelas bersama 
gurunya. Keaktifan adalah serangkaian kegiatan yang dilakukan oleh siswa kelas 5 SDN Lodoyong 03 Kecamatan Ambarawa yang dapat diamati oleh guru secara klasikal, yang tercermin dalam kegiatan fisik ketika melakukan proses pembelajaran di kelas.

Adapun teknik yang digunakan peneliti untuk mengumpulkan data yang berkaitan dengan hasil belajar dan keaktifan belajar siswa antara lain.

a. Tes, dilakukan untuk mengumpulkan data tentang hasil belajar siswa pada materi matematika.

b. Observasi, berupa observasi aktivitas guru dan siswa. Observasi aktivitas guru dilakukan untuk mengamati kegiatan mengajar guru, sedangkan observasi siswa dilakukan untuk mengamati dan mengukur keaktifan siswa dalam pembelajaran.

c. Dokumentasi untuk mendokumentasikan kegiatan-kegiatan dalam proses pembelajaran.

d. Wawancara untuk mengumpulkan data awal terkait dengan hasil belajar siswa.

Instrumen yang digunakan dalam penelitian ini antara lain.

a. Lembar evaluasi yang berisi butir-butir soal berbentuk isian dan uraian.

b. Lembar observasi aktivitas guru dan lembar observasi aktivitas siswa.

c. Lembar wawancara untuk guru dan lembar wawancara untuk siswa.

Indikator kinerja dalam penelitian ini yaitu:

a. Hasil belajar $80 \%$ siswa atau sekitar 17 siswa harus mencapai ketuntasan $\geq$ KKM sebesar 70.

b. Rata-rata tingkat keaktifan siswa secara klasikal harus mencapai $\geq 80 \%$ aktif. Teknik yang digunakan dalam menganalisis data dalam penelitian ini ada dua yaitu analisis ketuntasan dan analisis komparatif. Analisis ketuntasan dilakukan dengan membandingkan data hasil belajar dengan KKM. Sedangkan analisis komparatif dilakukan dengan membandingkan data hasil belajar pada pra siklus, siklus I, dan siklus II. Data keaktifan siswa juga dianalisis dengan cara yang sama, yaitu dengan membandingkan skor rata-rata keaktifan siswa pada siklus I dan siklus II.

\section{HASIL DAN PEMBAHASAN}

\section{Kondisi Pra Siklus}

Berdasarkan kegiatan wawancara terhadap guru kelas 5 SDN Lodoyong 03 Kecamatan Ambarawa, diperoleh keterangan bahwa sebagian besar siswa kelas 5 mengalami kesulitan belajar pada materi matematika di semester II. Data ini didukung dengan rendahnya hasil belajar mereka yang bersumber dari hasil Ulangan Tengah Semester II Tahun Pelajaran 2013/2014 pada mata pelajaran matematika yang diperoleh sebagai berikut. 
Upaya Peningkatan Keaktifan dan Hasil Belajar Matematika melalui Pendekatan Contextual Teaching And Learning (CTL) Berbantuan Alat Peraga (Nova Dinda Taurina \& Wasitohadi)

Tabel 1

Hasil Belajar Matematika Siswa Kelas 5 SDN Lodoyong 03 Kecamatan Ambarawa pada Pra Siklus

\begin{tabular}{|c|c|c|c|c|}
\hline \multirow{2}{*}{ No } & Interval Nilai & \multicolumn{2}{|c|}{ Sebelum Tindakan } & \multirow{2}{*}{ Keterangan } \\
\cline { 3 - 4 } & & Jumlah & Persentase & \\
\hline 1 & $45-52$ & 4 & $19 \%$ & Tidak tuntas \\
\hline 2 & $53-60$ & 4 & $19 \%$ & Tidak tuntas \\
\hline 3 & $61-68$ & 5 & $23,8 \%$ & Tidak tuntas \\
\hline 4 & $69-76$ & 2 & $9,6 \%$ & Tuntas \\
\hline 5 & $77-84$ & 1 & $4,8 \%$ & Tuntas \\
\hline 6 & $85-92$ & 5 & $23,8 \%$ & Tuntas \\
\hline \multicolumn{2}{|c|}{ Jumlah } & 21 & $100 \%$ & \\
\hline
\end{tabular}

Dari tabel 1 terlihat bahwa pada nilai 45 s/d 52 dicapai oleh 4 siswa dengan persentase $19 \%$, pada nilai $53 \mathrm{~s} / \mathrm{d} 60$ dicapai 4 siswa dengan persentase $19 \%$, pada nilai $61 \mathrm{~s} / \mathrm{d} 68$ dicapai 5 siswa dengan persentase 23,8\%. Sedangkan pada nilai yang lebih tinggi yaitu $69 \mathrm{~s} / \mathrm{d} 76$ dicapai 2 siswa dengan persentase $9,6 \%$, pada nilai 77 s/d 84 hanya dicapai 1 siswa dengan persentase 4,8\%, dan pada nilai 85 s/d 92 dicapai 5 siswa dengan persentase $23,8 \%$. Grafik hasil belajar siswa pada pra siklus dapat dilihat pada gambar 1 berikut ini.

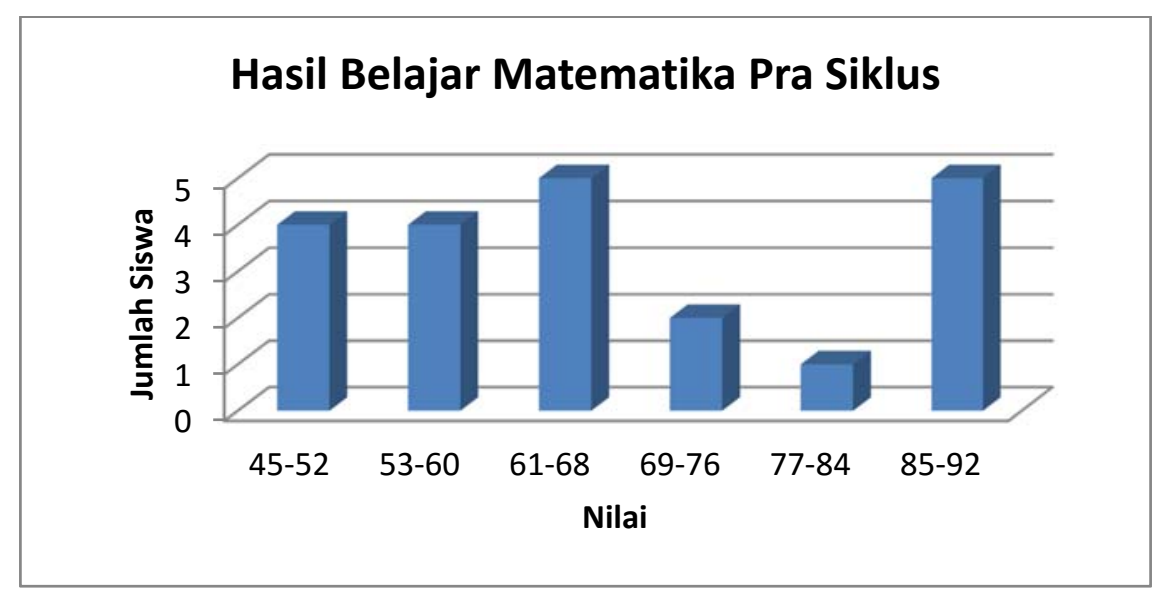

Gambar 1 Grafik hasil belajar matematika pra siklus siswa kelas 5

SDN Lodoyong 03 Ambarawa

Berdasarkan data hasil belajar pra siklus siswa pada mata pelajaran matematika di atas, maka direncanakan sebuah penelitian tindakan kelas dengan tujuan untuk 
mengubah situasi tersebut. PTK ini dilakukan dengan menerapkan pendekatan CTL berbantuan alat peraga. Adapun pelaksanaannya dijelaskan pada bagian berikut ini.

\section{Siklus I}

Pelaksanaan tindakan pada siklus I dilakukan melalui tiga kali pertemuan. Pertemuan pertama dilaksanakan pada hari Rabu 2 Maret 2014, pertemuan kedua dilaksanakan pada hari Jumat 4 April, dan pertemuan ketiga dilaksanakan pada hari Senin 7 April 2014. Pada pelaksanaan tindakan siklus I ini guru melakukan pembelajaran matematika dengan pokok bahasan perkalian dan pembagian berbagai bentuk pecahan.

Dalam pelaksanaan tindakan siklus ini dibagi menjadi beberapa tahap. Tahap pertama (Konstruksi), guru bersama siswa melakukan tanya jawab tentang pengalaman nyata siswa yang berkaitan dengan materi perkalian dan pembagian pecahan. Kegiatan ini dilakukan dengan menggunakan alat peraga. Tahap kedua (Inkuiri), guru mengajukan permasalahan kontekstual terkait dengan materi. Kemudian siswa diminta untuk mencari penyelesaian dari permasalahan tersebut. Tahap ketiga (Bertanya), guru mengajukan pertanyaan kepada siswa. Kemudian siswa diminta menjawab pertanyaan tersebut. Selain itu guru juga dapat memberikan kesempatan kepada siswa untuk menanyakan materi yang belum mereka pahami. Tahap keempat (Masyarakat belajar), guru membentuk siswa dalam kelompok secara heterogen untuk melakukan kerja kelompok, masing-masing kelompok terdiri dari 2 hingga 3 siswa. Kemudian hasil kerja kelompok dipresentasikan siswa di depan kelas. Siswa lainnya diminta untuk menanggapi. Pada tahap kelima (Pemodelan), guru memberikan memberikan umpan balik kepada siswa dengan memberikan contoh tentang cara pengerjaan soal yang benar.

\section{a. Hasil Belajar}

Tabel 2

\section{Hasil Belajar Matematika Siswa Kelas 5 SDN Lodoyong 03 Ambarawa Siklus I}

\begin{tabular}{|c|c|c|c|c|}
\hline \multirow{2}{*}{ No } & Interval Nilai & \multicolumn{2}{|c|}{ Sebelum Tindakan } & \multirow{2}{*}{ Keterangan } \\
\cline { 3 - 4 } & & Jumlah & Persentase & \\
\hline 1 & $25-39$ & 3 & $14,3 \%$ & Tidak tuntas \\
\hline 2 & $40-54$ & 2 & $9,5 \%$ & Tidak tuntas \\
\hline 3 & $55-69$ & 3 & $14,3 \%$ & Tidak tuntas \\
\hline 4 & $70-84$ & 7 & $33,3 \%$ & Tuntas \\
\hline 5 & $85-100$ & 6 & $28,6 \%$ & Tuntas \\
\hline \multicolumn{2}{r|}{ Jumlah } & 21 & $100 \%$ & \\
\hline
\end{tabular}

Tahap keenam (Refleksi), guru bersama dengan siswa membuat rangkuman atau kesimpulan tetang materi perkalian dan pembagian pecahan. Pembuatan rangkuman 
ini dilakukan dalam dua macam cara yaitu secara lisan dan secara tertulis. Tahap ketujuh (Penilaian), guru memberikan soal evaluasi untuk dikerjakan siswa. Penilaian ini dilakukan untuk mengukur kemampuan siswa secara individu. Berdasarkan keterangan pada tabel 2, dapat digambarkan grafiknya berikut ini.

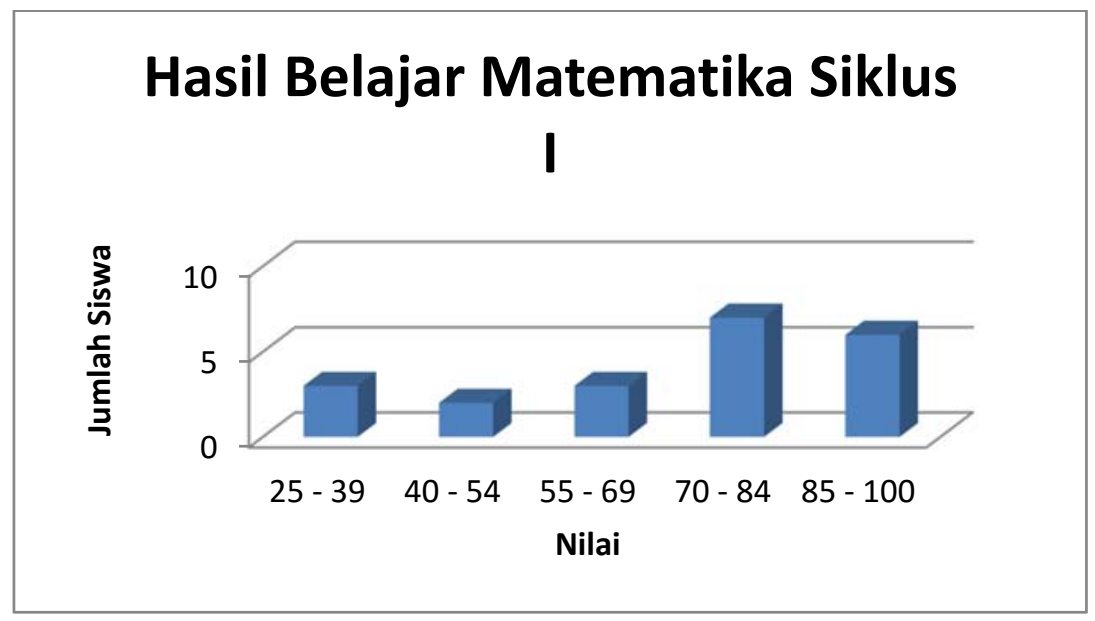

Gambar 2 Grafik hasil belajar matematika siklus I siswa kelas 5 SDN Lodoyong 03 Kecamatan Ambarawa

Data hasil belajar berdasarkan tabel 2 Berikut diuraikan hasil analisis ketuntasan hasil belajar siklus I.

Tabel 3

Analisis Ketuntasan Hasil Belajar Matematika Siswa Kelas 5 SDN Lodoyong 03 Ambarawa Siklus I

\begin{tabular}{|c|c|c|c|c|}
\hline \multirow{2}{*}{ No. } & \multicolumn{2}{|c|}{ Standar Ketuntasan } & \multirow{2}{*}{$\begin{array}{c}\text { Jumlah } \\
\text { Siswa }\end{array}$} & \multirow{2}{*}{ Persentase } \\
\cline { 2 - 3 } & Angka & Ketuntasan & & \\
\hline 1 & $<70$ & Tidak tuntas & 8 & $38 \%$ \\
\hline 2 & $\geq 70$ & Tuntas & 13 & $62 \%$ \\
\hline Jumlah & 21 & $100 \%$ \\
\hline \multicolumn{2}{|l|}{ Nilai tertinggi } & 100 & \\
\hline \multicolumn{2}{|l|}{ Nilai terendah } & 25 & \\
\hline \multicolumn{2}{|l|}{ Rata-rata } & 69 & \\
\hline
\end{tabular}

Dari tabel 3 terlihat bahwa sebanyak 13 siswa telah mencapai ketuntasan. Sedangkan 8 siswa lainnya belum atau tidak mencapai ketuntasan. Nilai terendah siswa adalah 25, nilai tertinggi siswa adalah 100, dan nilai rata-rata siswa hanya 69. 
Untuk melihat ada tidaknya peningkatan hasil belajar, berikut diuraikan hasil analisis komparatif pada pra siklus dan siklus I.

\section{Tabel 4}

\section{Analisis Komparatif Ketuntasan Hasil Belajar Matematika Siswa Kelas 5 SDN Lodoyong 03 Ambarawa}

\begin{tabular}{|c|l|c|c|c|c|}
\hline \multirow{2}{*}{ No } & \multirow{2}{*}{ Ketuntasan } & \multicolumn{2}{|c|}{ Pra Siklus } & \multicolumn{2}{c|}{ Siklus I } \\
\cline { 3 - 6 } & & $\mathrm{f}$ & $(\%)$ & $\mathrm{f}$ & $(\%)$ \\
\hline 1 & Tidak tuntas & 13 & $62 \%$ & 8 & $38 \%$ \\
\hline 2 & Tuntas & 8 & $38 \%$ & 13 & $62 \%$ \\
\hline Rata-rata & \multicolumn{2}{|c|}{67} & \multicolumn{2}{|c|}{69} \\
\hline Nilai tertinggi & \multicolumn{2}{|c|}{91} & \multicolumn{2}{|c|}{100} \\
\hline Nilai terendah & \multicolumn{2}{|c|}{45} & \multicolumn{2}{|c|}{25} \\
\hline
\end{tabular}

Berdasarkan tabel 4 terlihat bahwa ada peningkatan jumlah siswa yang tuntas. Pada pra siklus hanya 8 siswa yang tuntas, dan 13 siswa lainnya tidak tuntas. Sedangkan pada siklus I jumlah siswa yang tuntas mengalami peningkatan menjadi 13 siswa. Sehingga siswa yang tidak tuntas menjadi berkurang menjadi 8 siswa. Tidak jauh berbeda dari siklus I, siklus II juga mengalami peningkatan jumlah siswa yang tuntas yaitu menjadi 17 siswa. Sedangkan jumlah siswa yang tidak tuntas pada siklus II hanya 4 siswa.

\section{b. Keaktifan}

Pengumpulan data tentang keaktifan siswa dilakukan bersamaan dengan dimulainya pembelajaran, dan berakhir ketika pembelajaran selesai. Hasil observasi keaktifan siswa tersebut direkap dan dikategorikan menjadi 3 macam, yaitu Kurang Aktif (skor 0-6), Cukup Aktif (skor 7-12), dan Aktif (skor 13-17). Pada tabel 5 berikut diuraikan hasil observasi keaktifan siswa pada siklus I, untuk pertemuan 1, 2 dan 3. Berdasarkan tabel 5, menunjukkan bahwa rata-rata skor keaktifan siswa sebesar 12,3. Sehingga keaktifan siswa pada siklus I dapat dikategorikan Cukup Aktif. 
Tabel 5

Keaktifan Siswa Kelas 5 SDN Lodoyong 03 Ambarawa pada Pembelajaran Matematika Siklus I

\begin{tabular}{|c|c|c|c|c|}
\hline \multirow[t]{2}{*}{ No } & \multirow[t]{2}{*}{ Aspek yang Diamati } & \multicolumn{3}{|c|}{$\begin{array}{c}\text { Hasil } \\
\text { Observasi } \\
\text { Pertemuan ke }\end{array}$} \\
\hline & & 1 & 2 & 3 \\
\hline 1 & Siswa terlibat dalam kegiatan apersepsi & $\sqrt{ }$ & $\sqrt{ }$ & $\sqrt{ }$ \\
\hline 2 & $\begin{array}{l}\text { Siswa memperhatikan secara seksama ketika } \\
\text { disampaikan tujuan pembelajaran }\end{array}$ & $\sqrt{ }$ & $\sqrt{ }$ & $\sqrt{ }$ \\
\hline 3 & $\begin{array}{l}\text { Siswa memperhatikan dengan serius ketika } \\
\text { dijelaskan materi pelajaran }\end{array}$ & $\mathrm{x}$ & $\sqrt{ }$ & $\sqrt{ }$ \\
\hline 4 & $\begin{array}{l}\text { Siswa memperhatikan alat peraga yang disajikan } \\
\text { guru }\end{array}$ & $\sqrt{ }$ & $\sqrt{ }$ & $\sqrt{ }$ \\
\hline 5 & $\begin{array}{l}\text { Siswa aktif menggunakan alat peraga sesuai petunjuk } \\
\text { guru }\end{array}$ & $\mathrm{x}$ & $\sqrt{ }$ & $\sqrt{ }$ \\
\hline 6 & Siswa aktif dalam pemecahan masalah kontekstual & $\sqrt{ }$ & $\mathrm{x}$ & $\sqrt{ }$ \\
\hline 7 & Siswa aktif bertanya saat proses pembelajaran & $\mathrm{x}$ & $\mathrm{x}$ & $\sqrt{ }$ \\
\hline 8 & Siswa aktif menjawab pertanyaan yang diajukan guru & $\sqrt{ }$ & $\sqrt{ }$ & $\sqrt{ }$ \\
\hline 9 & Siswa aktif mengungkapkan pendapatnya & $\mathrm{x}$ & $\mathrm{x}$ & $\mathrm{x}$ \\
\hline 10 & Siswa aktif mengerjakan latihan soal dari guru & $\sqrt{ }$ & $\sqrt{ }$ & $\sqrt{ }$ \\
\hline 11 & Siswa aktif mencatat penjelasan guru & $\sqrt{ }$ & $\sqrt{ }$ & $\sqrt{ }$ \\
\hline 12 & Siswa bersemangat dalam bekerja kelompok & $\sqrt{ }$ & $\mathrm{x}$ & $\mathrm{x}$ \\
\hline 13 & $\begin{array}{l}\text { Siswa dapat bersosialisasi dengan siswa lain, untuk } \\
\text { saling membantu dalam kerja kelompok }\end{array}$ & $\sqrt{ }$ & $\mathrm{x}$ & $\mathrm{x}$ \\
\hline 14 & $\begin{array}{l}\text { Siswa aktif mempresentasikan hasil kerjanya dengan } \\
\text { baik }\end{array}$ & $\sqrt{ }$ & $\mathrm{x}$ & $\sqrt{ }$ \\
\hline 15 & Siswa memperhatikan umpan balik dari guru & $\sqrt{ }$ & $\sqrt{ }$ & $\sqrt{ }$ \\
\hline 16 & Siswa aktif merangkum materi & $\mathrm{x}$ & $\sqrt{ }$ & $\sqrt{ }$ \\
\hline 17 & Siswa aktif mengerjakan evaluasi & $\sqrt{ }$ & $\sqrt{ }$ & $\sqrt{ }$ \\
\hline & $\begin{array}{l}\text { Skor total } \\
\end{array}$ & 12 & 11 & 14 \\
\hline & Rata-rata & \multicolumn{3}{|c|}{12,3} \\
\hline
\end{tabular}

\section{Siklus II}

Pelaksanaan tindakan siklus II dilakukan melalui tiga kali pertemuan. Pertemuan pertama dilaksanakan pada hari Jumat 11 April 2014, pertemuan kedua dilaksanakan pada hari Senin 14 April 2014, dan pertemuan ketiga dilaksanakan 
pada hari Sabtu 19 April 2014. Pada pelaksanaan tindakan siklus II ini guru melakukan pembelajaran matematika dengan pokok bahasan perbandingan dan skala.

Dalam pelaksanaan tindakan siklus ini dibagi menjadi beberapa tahap. Tahap pertama (Konstruksi), guru bersama siswa melakukan tanya jawab tentang pengalaman siswa berkaitan dengan materi perbandingan dan skala dengan menggunakan alat peraga. Tahap kedua (Inkuiri), guru mengajukan permasalahan kontekstual terkait dengan materi tersebut. Kemudian siswa diminta untuk mencari penyelesaiannya. Tahap ketiga (Bertanya), guru mengajukan pertanyaan, kemudian siswa diminta menjawab pertanyaan tersebut. Selain itu guru juga memberikan kesempatan siswa untuk menanyakan materi yang belum mereka pahami. Tahap keempat (Masyarakat belajar), guru membentuk siswa dalam kelompok secara heterogen untuk melakukan kerja kelompok, masing-masing kelompok terdiri dari 5 siswa. Kemudian hasil kerja kelompok dipresentasikan siswa di depan kelas dan siswa lainnya diminta untuk menanggapi. Pada tahap kelima (Pemodelan), guru memberikan memberikan umpan balik kepada siswa dengan memberikan contoh tentang cara pengerjaan soal yang benar. Tahap keenam (Refleksi), guru bersama dengan siswa membuat rangkuman tentang materi perbandingan dan skala. Tahap ketujuh (Penilaian), guru memberikan soal evaluasi untuk dikerjakan siswa.

\section{a. Hasil Belajar}

\section{Tabel 4}

Hasil Belajar Matematika Siswa Kelas 5 SDN Lodoyong 03 Ambarawa Siklus II

\begin{tabular}{|c|c|c|c|c|}
\hline \multirow{2}{*}{ No } & \multirow{2}{*}{ Interval Nilai } & \multicolumn{2}{|c|}{ Sebelum Tindakan } & \multirow{2}{*}{ Keterangan } \\
\cline { 3 - 4 } & & Jumlah & Persentase & \\
\hline 1 & $40-49$ & 2 & $9,5 \%$ & Tidak tuntas \\
\hline 2 & $50-59$ & 1 & $4,8 \%$ & Tidak tuntas \\
\hline 3 & $60-69$ & 1 & $4,8 \%$ & Tidak tuntas \\
\hline 4 & $70-79$ & 6 & $28,6 \%$ & Tuntas \\
\hline 5 & $80-89$ & 5 & $23,7 \%$ & Tuntas \\
\hline 6 & $90-100$ & 6 & $28,6 \%$ & Tuntas \\
\hline \multicolumn{2}{|c|}{ Jumlah } & 21 & $100 \%$ & \\
\hline
\end{tabular}

Berdasarkan keterangan pada tabel 4, dapat digambarkan grafiknya berikut ini. 


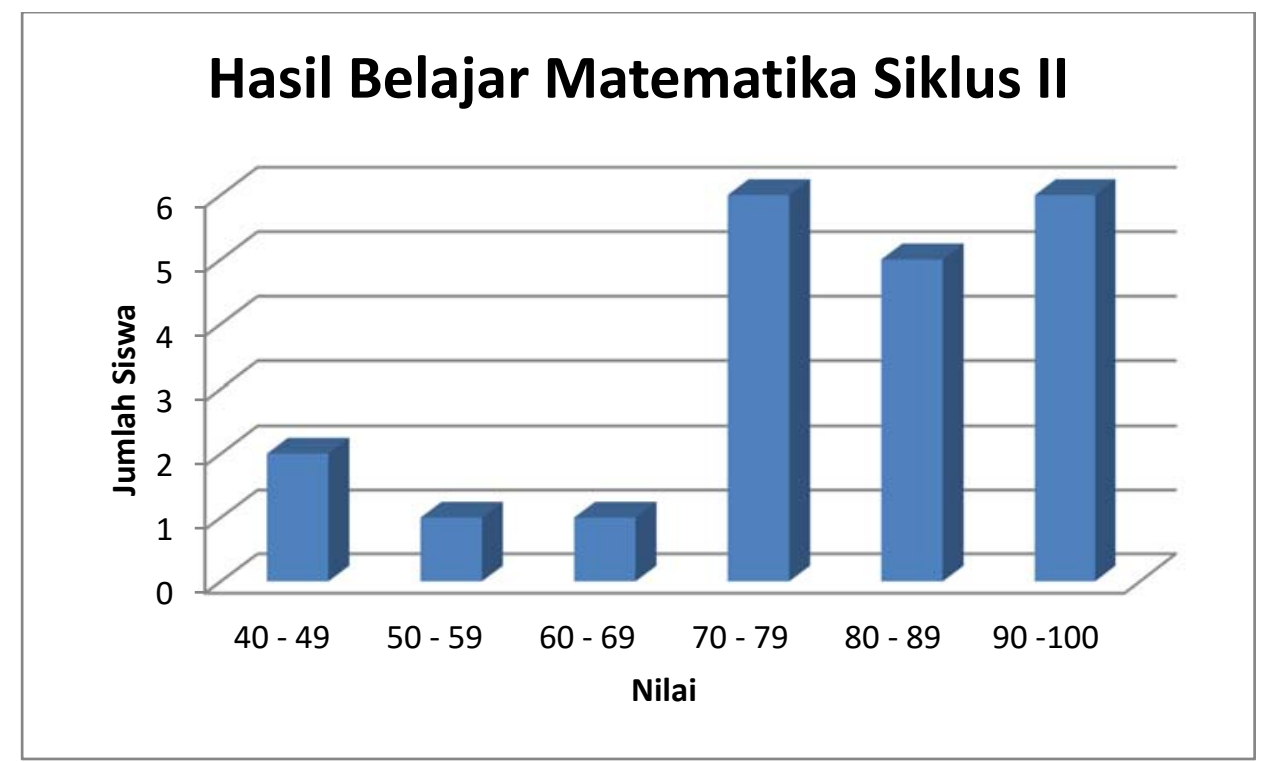

Gambar 3 Grafik hasil belajar matematika siklus II siswa kelas 5

SDN Lodoyong 03 Kecamatan Ambarawa

Analisis Ketuntasan Hasil Belajar Siklus II

Data hasil belajar berdasarkan tabel 4 , berikut diuraikan hasil analisis ketuntasan hasil belajar siklus II.

Tabel 5

Analisis Ketuntasan Hasil Belajar Matematika Siswa Kelas 5 SDN Lodoyong 03 Ambarawa Siklus II

\begin{tabular}{|c|c|c|c|c|}
\hline \multirow{2}{*}{ No. } & \multicolumn{2}{|c|}{ Standar Ketuntasan } & \multirow{2}{*}{$\begin{array}{c}\text { Jumlah } \\
\text { Siswa }\end{array}$} & \multirow{2}{*}{ Persentase } \\
\hline & Angka & Ketuntasan & & \\
\hline 1 & $<70$ & Tidak tuntas & 4 & $19 \%$ \\
\hline 2 & $\geq 70$ & Tuntas & 17 & $81 \%$ \\
\hline \multicolumn{3}{|c|}{ Jumlah } & 21 & $100 \%$ \\
\hline \multicolumn{3}{|c|}{ Nilai tertinggi } & 100 & \\
\hline \multicolumn{3}{|c|}{ Nilai terendah } & 40 & \\
\hline \multicolumn{3}{|c|}{ Rata-rata } & 76,4 & \\
\hline
\end{tabular}

Berdasarkan tabel 5 terlihat bahwa dari 21 siswa yang ada, sebanyak 17 siswa (81\%) telah berhasil mencapai ketuntasan belajar. Sedangkan 4 siswa lainnya (19\%) belum mencapai ketuntasan belajar. Nilai terendah adalah 40, nilaoi tertinggi adalah 100, dan nilai rata-rata meningkat menjadi 76,4.

Untuk melihat ada tidaknya peningkatan hasil belajar, berikut diuraikan hasil analisis komparatif pada pra siklus dan siklus II. 
Tabel 6

Analisis Komparatif Ketuntasan Hasil Belajar Matematika Siswa Kelas 5 SDN Lodoyong 03 Ambarawa

\begin{tabular}{|c|l|c|c|c|c|c|c|}
\hline \multirow{2}{*}{ No } & \multirow{2}{*}{ Ketuntasan } & \multicolumn{2}{|c|}{ Pra Siklus } & \multicolumn{2}{c|}{ Siklus I } & \multicolumn{2}{c|}{ Siklus II } \\
\cline { 3 - 8 } & & $\mathrm{f}$ & $(\%)$ & $\mathrm{f}$ & $(\%)$ & $\mathrm{f}$ & $(\%)$ \\
\hline 1 & Tidak tuntas & 13 & $62 \%$ & 8 & $38 \%$ & 4 & $19 \%$ \\
\hline 2 & Tuntas & 8 & $38 \%$ & 13 & $62 \%$ & 17 & $81 \%$ \\
\hline Rata-rata & \multicolumn{2}{|c|}{67} & \multicolumn{2}{|c|}{69} & \multicolumn{2}{c|}{76.4} \\
\hline Nilai tertinggi & \multicolumn{2}{|c|}{91} & \multicolumn{2}{|c|}{100} & \multicolumn{2}{c|}{100} \\
\hline Nilai terendah & \multicolumn{2}{|c|}{45} & \multicolumn{2}{c|}{25} & \multicolumn{2}{c|}{40} \\
\hline
\end{tabular}

Berdasarkan tabel 6 terlihat bahwa ada peningkatan jumlah siswa yang tuntas. Pada pra siklus hanya 8 siswa yang tuntas, dan 13 siswa lainnya tidak tuntas. Sedangkan pada siklus I, jumlah siswa yang tuntas mengalami peningkatan menjadi 13 siswa dan siswa yang tidak tuntas berkurang menjadi 8 siswa. Tidak jauh berbeda dari siklus I, siklus II juga mengalami peningkatan jumlah siswa yang tuntas yaitu menjadi 17 siswa. Sedangkan jumlah siswa yang tidak tuntas pada siklus II hanya 4 siswa.

\section{b. Keaktifan}

Tabel 7

Keaktifan Siswa Kelas 5 SDN Lodoyong 03 Ambarawa pada Pembelajaran Matematika Siklus II

\begin{tabular}{|c|l|c|c|c|}
\hline \multirow{2}{*}{ No } & \multicolumn{1}{|c|}{ Aspek yang Diamati } & \multicolumn{3}{|c|}{$\begin{array}{c}\text { Hasil Observasi } \\
\text { Pertemuan ke }\end{array}$} \\
\cline { 3 - 6 } & \multicolumn{1}{|c|}{\begin{tabular}{l}
\multicolumn{1}{|c|}{} \\
\cline { 3 - 6 }
\end{tabular}} & $\sqrt{ }$ & $\sqrt{ }$ & $\sqrt{ }$ \\
\hline 1 & Siswa terlibat dalam kegiatan apersepsi & $\sqrt{ }$ & $\sqrt{ }$ & $\sqrt{ }$ \\
\hline 2 & $\begin{array}{l}\text { Siswa memperhatikan secara seksama ketika disampaikan } \\
\text { tujuan pembelajaran }\end{array}$ & $\begin{array}{l}\text { X } \\
\text { pelajaran }\end{array}$ & $\sqrt{ }$ & $\sqrt{ }$ \\
\hline 4 & Siswa memperhatikan alat peraga yang disajikan guru & $\sqrt{ }$ & $\sqrt{ }$ & $\sqrt{ }$ \\
\hline 5 & Siswa aktif menggunakan alat peraga sesuai petunjuk guru & $\sqrt{ }$ & $\sqrt{ }$ & $\sqrt{ }$ \\
\hline 6 & Siswa aktif dalam pemecahan masalah kontekstual & $\sqrt{ }$ & $\sqrt{ }$ & $\sqrt{ }$ \\
\hline 7 & Siswa aktif bertanya saat proses pembelajaran & $\sqrt{ }$ & $\sqrt{ }$ & $\sqrt{ }$ \\
\hline 8 & Siswa aktif menjawab pertanyaan yang diajukan guru & $\sqrt{ }$ & $\sqrt{ }$ & $\sqrt{ }$ \\
\hline 9 & Siswa aktif mengungkapkan pendapatnya & x & $\sqrt{ }$ & $\sqrt{ }$ \\
\hline
\end{tabular}


Upaya Peningkatan Keaktifan dan Hasil Belajar Matematika melalui Pendekatan Contextual Teaching And Learning (CTL) Berbantuan Alat Peraga (Nova Dinda Taurina \& Wasitohadi)

\begin{tabular}{|c|l|c|c|c|}
\hline 10 & Siswa aktif mengerjakan latihan soal dari guru & $\sqrt{ }$ & $\sqrt{ }$ & $\sqrt{ }$ \\
\hline 11 & Siswa aktif mencatat penjelasan guru & $\sqrt{ }$ & $\sqrt{ }$ & $\sqrt{ }$ \\
\hline 12 & Siswa bersemangat dalam bekerja kelompok & $\mathrm{x}$ & $\sqrt{ }$ & $\sqrt{ }$ \\
\hline 13 & $\begin{array}{l}\text { Siswa dapat bersosialisasi dengan siswa lain, untuk saling } \\
\text { membantu dalam kerja kelompok }\end{array}$ & $\mathrm{x}$ & $\sqrt{ }$ & $\sqrt{ }$ \\
\hline 14 & Siswa aktif mempresentasikan hasil kerjanya dengan baik & $\sqrt{ }$ & $\mathrm{x}$ & $\sqrt{ }$ \\
\hline 15 & Siswa memperhatikan umpan balik dari guru & $\sqrt{ }$ & $\sqrt{ }$ & $\sqrt{ }$ \\
\hline 16 & Siswa aktif merangkum materi & $\sqrt{ }$ & $\sqrt{ }$ & $\sqrt{ }$ \\
\hline 17 & Siswa aktif mengerjakan evaluasi & $\sqrt{ }$ & $\sqrt{ }$ & $\sqrt{ }$ \\
\hline \multicolumn{2}{|}{ Skor total } & 13 & 16 & 17 \\
\hline Rata-rata & \multicolumn{3}{|c|}{15,3} \\
\hline
\end{tabular}

Berdasarkan tabel 7, menunjukkan bahwa rata-rata skor keaktifan siswa sebesar 15,3. Sehingga keaktifan siswa pada siklus II dapat dikategorikan Aktif.

Analisis Komparatif Keaktifan Siswa Siklus II

Berikut ini disajikan data keaktifan siswa pada siklus I dan siklus II, untuk mengetahui ada tidaknya peningkatan keaktifan siswa dalam pembelajaran matematika.

Tabel 8

Analisis Komparatif Keaktifan Siswa Kelas 5 SDN Lodoyong 03 Ambarawa dalam Pembelajaran Matematika

\begin{tabular}{|c|c|c|c|c|c|}
\hline \multirow{2}{*}{ No } & \multirow{2}{*}{$\begin{array}{c}\text { Standar } \\
\text { Ketuntasan }\end{array}$} & $\begin{array}{c}\text { Siklus } \\
\text { Ke- }\end{array}$ & $\begin{array}{c}|c| \\
\text { Thor } \\
\text { Rata-rata }\end{array}$ & $\mathbf{2} \%)$ & \multirow{2}{*}{ Keterangan } \\
\hline 1 & \multirow{2}{*}{$80 \%$ aktif } & I & 12,3 & $72 \%$ & Cukup aktif \\
\cline { 3 - 5 } & II & 15,3 & $90 \%$ & Aktif \\
\hline
\end{tabular}

Berdasarkan tabel 8 terlihat bahwa ada peningkatan keaktifan siswa pada pembelajaran matematika siklus I dan siklus II. Pada siklus I skor rata-rata keaktifan siswa hanya 12,3 dengan persentase $72 \%$. Sehingga tingkat keaktifan siswa pada siklus ini dapat dikategorikan Cukup aktif. Sedangkan pada siklus II skor rata-rata keaktifan siswa meningkat menjadi 15,3 dengan persentase 90\%, maka dapat dikategorikan Aktif.

\section{Pembahasan}

Berdasarkan data hasil belajar dan keaktifan siswa yang diperoleh pada pra siklus, siklus I dan siklus II, dapat dikatakan bahwa terjadi peningkatan hasil belajar dan keaktifan siswa kelas 5 SDN Lodoyong 03 Kecamatan Ambarawa setelah 
diterapkan pendekatan CTL berbantuan alat peraga dalam pembelajaran matematika. Hal tersebut dapat terjadi karena beberapa alasan yang berkaitan dengan teori yang dikemukakan oleh beberapa ahli. Alasan pertama, pendekatan CTL dapat meningkatkan pemahaman siswa pada materi matematika. Menurut Depdiknas dalam Kesuma, dkk (2010:58), pendekatan CTL adalah pendekatan pembelajaran yang membantu guru mengaitkan materi yang diajarkan dengan situasi dunia nyata dan mendorong siswa membuat hubungan antara pengetahuan yang dimilikinya dengan kehidupan mereka sehari-hari. Pengaitan itu terbukti dapat membuat siswa kelas 5 SDN Lodoyong 03 Kecamatan Ambarawa mampu memahami materi dengan baik. Pemahaman yang baik terhadap materi matematika tersebut dibuktikan dengan hasil belajar mereka yang tinggi.

Alasan kedua, pendekatan CTL mampu membuat siswa aktif dalam pembelajaran matematika. Langkah-langkah pendekatan CTL seperti yang dikemukakan oleh Nurhadi sangat beragam, seperti: (a) konstruksi, (b) inkuiri, (c) bertanya, (d) masyarakat belajar/ kerja kelompok, (e) pemodelan, (f) refleksi, dan (g) penilaian autentik/ sebenarnya, telah terbukti dapat membuat siswa aktif dalam belajar karena siswa dapat belajar dengan banyak interaksi yaitu guru ke siswa, siswa ke guru, dan siswa ke siswa.

Alasan ketiga, alat peraga dapat membantu memperjelas materi matematika dan mampu menarik perhatian siswa. Menurut Sudjana (2002:59), alat peraga dalam pengajaran memegang peran penting sebagai alat bantu untuk menciptakan proses belajar mengajar yang efektif. Pernyataan tersebut telah terbukti dan terlihat ketika siswa kelas 5 SDN Lodoyong 03 Kecamatan Ambarawa dijelaskan materi dengan bantuan alat peraga baik berupa benda konkrit maupun benda semi konkrit, mereka menjadi tertarik dalam pembelajaran tersebut. Selain itu penggunaan alat peraga mampu membantu siswa dalam memperjelas materi pelajaran matematika yang disampaikan guru dengan lebih baik. Hal itu dibuktikan dengan pencapaian hasil belajar mereka dan tingkat keaktifan belajar siswa yang tinggi.

Selain teori para ahli, hasil penelitian ini sejalan dengan penelitian terdahulu yang dilakukan oleh Muhamad Ngainun Najib (2013) dengan judul "Upaya Peningkatan Hasil Belajar IPA melalui Pendekatan CTL dan Penggunaan Alat Peraga pada Siswa Kelas 5 di SD Negeri Koripan 04 Tahun 2012/2013”. Ia menyatakan bahwa pendekatan CTL dan penggunaan alat peraga dapat meningkatkan hasil belajar siswa IPA kelas 5 SD Negeri Koripan 04 Tahun 2012/2013. Selain itu menurut hasil penelitian oleh Husni Sabil (2011) yang berjudul "Penerapan Pembelajaran Contextual Teaching \& Learning (CTL) pada Materi Ruang Dimensi Tiga Menggunakan Model Pembelajaran Berdasarkan Masalah (MPBM) Mahasiswa Program Studi Matematika FKIP UNJA" juga menyatakan bahwa melalui penerapan pembelajaran Contextual Teaching \& Learning (CTL) dan model 
pembelajaran berdasarkan masalah (MPBM) dapat meningkatkan kualitas dan hasil belajar pada materi ruang dimensi tiga mahasiswa Program Studi Matematika FKIP UNJA.

\section{SIMPULAN DAN SARAN}

\section{Simpulan}

Berdasarkan hasil penelitian dan pembahasan, dapat disimpulkan bahwa pendekatan Contextual Teaching and Learning (CTL) berbantuan alat peraga dapat meningkatkan keaktifan dan hasil belajar matematika pada siswa kelas 5 SDN Lodoyong 03 Kecamatan Ambarawa Semester II Tahun Pelajaran 2013/2014. Hal ini terbukti dengan adanya peningkatan rata-rata hasil belajar siswa pada pra siklus yang hanya sebesar 67, kemudian pada siklus I naik menjadi 69, dan pada siklus II meningkat kembali menjadi 76,4. Jumlah ketuntasan belajar siswa juga meningkat, pada pra siklus hanya $38 \%$, pada siklus I $62 \%$, dan pada siklus II $81 \%$ dengan KKM 70. Selain itu keaktifan siswa pada pembelajaran siklus I dan siklus II juga mengalami peningkatan. Pada siklus I rata-rata tingkat keaktifan siswa hanya 12,3 atau $72 \%$ dengan kategori Cukup aktif. Kemudian pada siklus II rata-rata tingkat keaktifan siswa meningkat menjadi 15,3 atau 90\% dengan kategori Aktif.

\section{Saran}

Beberapa saran yang dapat peneliti berikan untuk meningkatkan keaktifan dan hasil belajar pada mata pelajaran matematika sebagai berikut.

\section{a. Bagi Sekolah}

Dengan adanya hasil penelitian tindakan kelas ini diharapkan dapat digunakan sebagai salah satu pedoman atau acuan terkait dalam penyelenggaraan pembelajaran matematika dengan menggunakan pendekatan Contextual Teaching and Learning (CTL) berbantuan alat peraga.

b. Bagi Guru

1. Dalam merancang pembelajaran matematika sebaiknya guru menggunakan pendekatan Contextual Teaching and Learning (CTL) dengan bantuan alat peraga, karena pendekatan tersebut dapat mempermudah siswa dalam memahami materi matematika dan memberikan mereka pengalaman belajar yang lebih nyata.

2. Sebelum mengajar sebaiknya guru mempersiapkan dengan matang semua perangkat pembelajarannya termasuk media pembelajaran berupa alat peraga yang bervariasi. 
3. Sebelum mengajar dengan pendekatan CTL sebaiknya guru memahami secara mendalam mengenai sintaks pembelajaran pendekatan CTL dan berlatih menerapkannya terlebih dahulu.

c. Bagi Siswa

1. Siswa yang belum memahami materi sebaiknya mau atau berani untuk menanyakannya kepada guru atau teman.

2. Siswa yang sudah memahami materi maupun yang belum memahami materi, sebaiknya dapat lebih aktif dalam proses pembelajaran agar hasil belajar dapat dicapai lebih optimal.

\section{DAFTAR PUSTAKA}

Badan Standar Nasional Pendidikan. 2006. Standai Isi untuk Satuan Pendidikan Dasar dan Menengah. Jakarta: Departemen Pendidikna Nasional Republik Indonesia.

Johnson, Elaine B. 2006. Contextual Teaching and Learning; Menjadikan Kegiatan Belajar Mengajar Mengasyikkan dan Bermakna. Terjemahan Ibnu Setiawan. Bandung: MLC.

Kesuma, Dharma, dkk. 2010. Contextual Teaching and Learning Sebuah Panduan Awal dalam Pengembangan PBM. Garut: Rahayasa.

Najib, Muhamad Ngainun. 2013. Upaya Peningkatan Hasil Belajar IPA Melalui Pendekatan CTL dan Penggunaan Alat Peraga pada Siswa Kelas 5 di SD Negeri Koripan 04 Tahun 2012/2013. Skripsi. Salatiga: Universitas Kristen Satya Wacana. http://repository.library.uksw.edu/handle/123456789/3826 .Website diunduh pada 24 April 2014.

Nurhadi, dkk. 2003. Pembelajaran Kontekstual dan Penerapannya dalam KBK.. Malang: Universitas Negeri Malang.

Sudjana, Nana. 2003. Dasar-dasar Proses Belajar Mengajar. Bandung: Sinar Baru Algensindo.

Undang-undang Republik Indonesia Nomor 20 Tahun 2003 tentang Sistem Pendidikan Nasional. Jakarta: Departemen Pendidikna Nasional Republik Indonesia.

Usman, Moh. Uzer. 2000. Menjadi Guru Profesional. Bandung: Rosda. 